\title{
Review of Laboratory Tests used in Monitoring Hepatitis B Response to Pegylated Interferon and Nucleos(t)ide Analog Therapy
}

Carla Osiowy, $P h D^{1, *}$

Carla Coffin, $M S c, M D^{2}$

Anton Andonov, MD, PhD ${ }^{1}$

\author{
Address \\ *,1Bloodborne Pathogens and Hepatitis, National Microbiology Laboratory, Public \\ Health Agency of Canada, 1015 Arlington St., Winnipeg, MB, R3E 3R2, Canada \\ Email: carla.osiowy@phac-aspc.gc.ca \\ ${ }^{2}$ Liver Unit, Division of Gastroenterology and Hepatology, Cumming School of \\ Medicine, University of Calgary, Calgary, AB, Canada
}

Published online: 2 July 2016

(C) The Author(s) 2016. This article is published with open access at Springerlink.com

This article is part of the Topical Collection on Viral Infections

Keywords Hepatitis B virus · Nucleos(t)ide analog • Peg-IFN • Antiviral therapy · qHBsAg • Monitoring response

\section{Opinion statement}

There are only two currently approved classes of hepatitis B virus (HBV) antiviral agents, pegylated interferon (Peg-IFN), and nucleos(t)ide analogs (NAs) for chronic HBV infection. Although Peg-IFN is used for a finite 48-week duration and offers a greater chance of sustained off-treatment virological response, it is poorly tolerated and can only be offered to selected patients. The NAs are well tolerated but require prolonged therapy due to risk of relapse with treatment cessation. There is evolving data that novel virological assays (e.g., quantitative hepatitis B surface antigen, quantitative hepatitis B core antigen, quantitative antibody to core protein) in combination with hepatitis $B$ genotype and more sensitive HBV DNA polymerase chain reaction (PCR) assays may be useful to predict response to IFN as well as off-treatment NA durability. Utilization of these clinical laboratory tests may be important given the development of novel anti-HBV therapies, hoping to achieve a cure for chronic hepatitis B infection. 


\section{Introduction}

Hepatitis B virus (HBV) infection is estimated to affect approximately $0.8-1.1 \%$ of Canadians $[1,2]$. Antiviral treatments approved and available in Canada for chronic hepatitis B (CHB) infection include interferon (standard or pegylated interferon (Peg-IFN)) and nucleos(t)ide analogs (NAs), including an L-nucleoside analog (lamivudine (LAM)), acyclic nucleoside phosphonates (adefovir dipivoxil (ADV) and tenofovir disoproxil fumarate (TDF)), and a D-cyclopentane class nucleoside analog (entecavir (ETV)) [3]. Although most Canadian provinces and territories provide some measure of health plan reimbursement or coverage for these treatments, there may be strict clinical restrictions imposed for reimbursement, especially for more expensive second-generation NA (i.e., TDF and ETV), which limits their use and effectiveness [46]. Treatment is normally restricted to CHB carriers in a prolonged immune-active phase of infection or with advanced liver disease. In both HBV e antigen (HBeAg)positive and HBeAg-negative patients, clinicians assess on-treatment response to NA by monitoring serum HBV DNA (i.e., suppression of viral replication), antibody to HBeAg (anti-HBe) seroconversion (in HBeAg-positive patients), normalization of serum liver transaminases, and improvement in liver stiffness or histology, as determined by transient elastography (FibroScan ${ }^{\circledR}$ ) or liver biopsy [7 ${ }^{\bullet}$, 8]. Large randomized clinical trials have demonstrated that achievement of these surrogate clinical endpoints lead to reduced risk of liver disease progression, hepatocellular carcinoma (HCC) development, and even fibrosis regression $[9,10]$. In contrast, the assessment of response to Peg-IFN therapy is mainly based on off-treatment virological and clinical markers. Thus, a "sustained virologic response" (SVR) to Peg-IFN therapy is defined as HBeAg loss (in HBeAg-positive patients), HBV DNA <2000 IU/ $\mathrm{mL}$, as well as persistent normalization of alanine aminotransferase (ALT) at 6 months after the end of treatment. HBsAg loss is rare but more likely to occur with Peg-IFN compared to NA treatment [11]. As discussed below, recent data indicate that quantitative hepatitis $\mathrm{B}$ surface antigen (qHBsAg), as well as HBV DNA testing, could predict SVR to Peg-IFN therapy and NA. Table 1 describes the summary of current international guidelines for NA cessation and definitions of treatment response and relapse following withdrawal.

This review will provide a comprehensive overview of clinical virological tests used in monitoring

\section{Table 1. Summary of current international guidelines for NA treatment cessation}

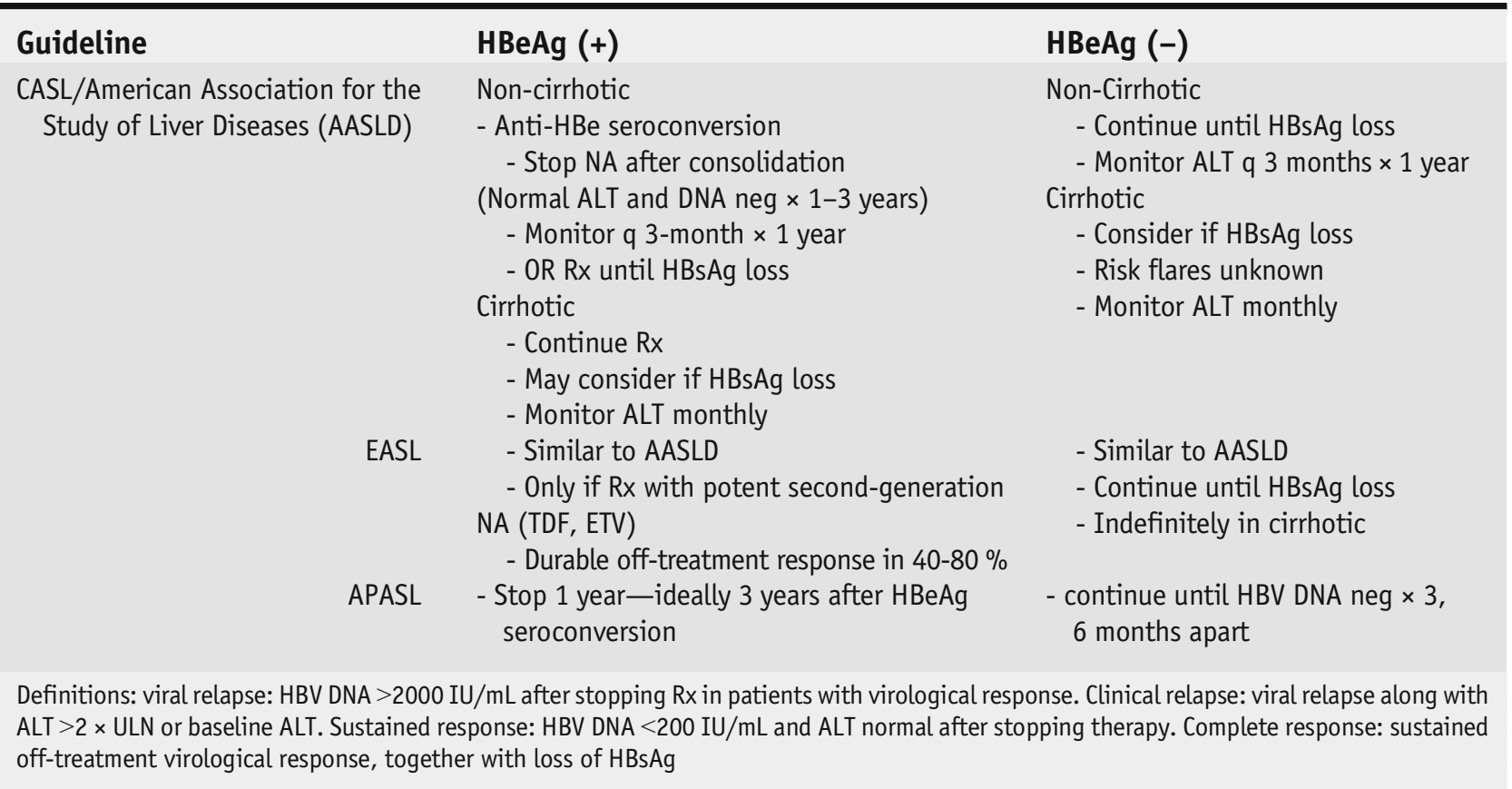


response to antiviral therapy for $\mathrm{CHB}$ infection, including the current assays for HBV DNA, more recent novel assays such as qHBsAg, and potential monitoring assays (Table 2).

\section{HBV DNA monitoring}

Monitoring of virological, serological, and clinical markers of infection during treatment and following its withdrawal is essential in evaluating treatment efficacy and patient response. Monitoring of serum HBV DNA has long been considered the best viral marker for management of chronic infection, due to the fundamental role of HBV DNA levels in disease progression and the persistent suppression of HBV DNA as a reliable endpoint goal of antiviral therapy [12•]. Long-term population-based studies have demonstrated the importance of serum HBV DNA levels in predicting the risk for development of severe end-stage liver disease outcomes [13]. Sensitive monitoring of HBV DNA during treatment has also established that stable suppression of HBV DNA to low or undetectable levels improves histologic outcomes and reverses fibrosis or cirrhosis $[8,14]$. Treatment management has been facilitated by improvement in HBV DNA quantitative technologies, allowing for increased sensitivity and dynamic range. Most clinical laboratories utilize commercially available real-time polymerase chain reaction (PCR) methods having sensitive limits of detection and quantification for measuring serum HBV DNA; however, other technologies, such as digital PCR, are being investigated as alternative methods, although standardization, ease of use, and optimization will be required to match the convenience and sensitivity of real-time PCR $[15,16]$.

Assay sensitivity, which determines the limit of HBV DNA detection and quantification, differs among commercial assays; thus, the definition of "undetectable DNA" in the literature and management guidelines will vary. Prior to the development of an HBV DNA standard IU for quantification, genome equivalents or copies were used, often resulting in significant variability among assays $[17,18]$. Due to this variability and use of assays having lower limits of detection, the findings of earlier studies investigating treatment response and cessation may not be comparable to later studies involving sensitive real-time PCR assays [19, 20].

Most management guidelines define virological response as "undetectable HBV DNA as measured by a sensitive PCR assay" [21, 22]. Practically, this translates into a range of values based on the detection limits of quantitative real time HBV PCR assays [23•]. Prior to 2007, most commercially available quantitative HBV DNA assays had a relatively narrow linear range and limit of detection (LoD) of approximately $200 \mathrm{IU} / \mathrm{mL}$. Current real-time PCR assays have an $8 \log _{10}$ linear range with very low LoD: $<6 \mathrm{IU} / \mathrm{mL}$ (Roche Cobas High Pure/Cobas TaqMan), $<10-15 \mathrm{IU} / \mathrm{mL}$ (Abbott m2000, dependent on the input volume), and $<20 \mathrm{IU} / \mathrm{mL}$ (Roche Cobas AmpliPrep/Cobas TaqMan) [24-26] (Table 2). However, we often observe that at the analytical LoD of the Roche Cobas High Pure/Cobas TaqMan assay, single specimen results may fluctuate 


\begin{tabular}{|c|c|c|}
\hline Test $^{\mathrm{a}}$ & Detection target & Interpretation and comments \\
\hline $\begin{array}{l}\text { Hepatitis B e antigen } \\
\quad(\mathrm{HBeAg})\end{array}$ & $\begin{array}{l}\text { Soluble protein produced } \\
\text { during acute or chronic } \\
\text { infection }\end{array}$ & $\begin{array}{l}\text { Indicates active viral replication and high } \\
\text { infectivity. Used to assess likelihood of chronic } \\
\text { hepatitis and HBV carriage. HBeAg status } \\
\text { indicates HBV infection phase and is used to } \\
\text { optimize treatment strategies. }\end{array}$ \\
\hline $\begin{array}{l}\text { Anti-hepatitis B e } \\
\text { antibody (Anti-HBe) }\end{array}$ & $\begin{array}{c}\text { Antibody produced in response } \\
\text { to the hepatitis } B \text { e antigen }\end{array}$ & $\begin{array}{l}\text { Indicates convalescence or } \\
\text { seroconversion/treatment response in } \\
\text { previously HBeAg-positive patients }\end{array}$ \\
\hline $\begin{array}{l}\text { Quantitative hepatitis B } \\
\text { surface antigen } \\
\text { (qHBsAg) }\end{array}$ & $\begin{array}{l}\text { HBV protein produced during } \\
\text { infection; either virion-associated, } \\
\text { subviral, or via integrated viral } \\
\text { DNA in the host genome. }\end{array}$ & $\begin{array}{l}\text { qHBsAg varies with HBV genotype and infection } \\
\text { phase and should be used together with HBV } \\
\text { DNA levels for interpretation of results. } \\
\text { Absolute } \mathrm{qHBsAg} \text { values (IU/mL) and rate of } \\
\text { decline can be used for response prediction. }\end{array}$ \\
\hline $\begin{array}{l}\text { Quantitative } \\
\text { anti-hepatitis B core } \\
\text { antibody (qAnti-HBc) }\end{array}$ & $\begin{array}{l}\text { Antibody produced in response } \\
\text { to the hepatitis B core } \\
\text { antigen ( } \mathrm{HBcAg})\end{array}$ & $\begin{array}{l}\text { Indicator of past, resolved, or persistent HBV } \\
\text { infection. Baseline anti-HBc levels may } \\
\text { indicate the magnitude of host immune } \\
\text { response against } \mathrm{HBV} \text {, predicting response to } \\
\text { therapy. qAnti-HBc testing is not routinely } \\
\text { used in management and requires international } \\
\text { standardization. }\end{array}$ \\
\hline $\begin{array}{l}\text { Quantitative hepatitis B } \\
\text { corerelated antigen } \\
\text { (qHBcrAg) }\end{array}$ & $\begin{array}{l}\text { Core antigen associated with } \\
\text { circulating viral particles, } \\
\text { denatured HBeAg and the } \\
\text { p22 core-related protein }\end{array}$ & $\begin{array}{l}\text { qHBcrAg is correlated with HBV DNA in } \\
\text { HBeAg-negative inactive patients and with } \\
\text { cccDNA levels. qHBcrAg is negatively predictive } \\
\text { for PEG-IFN response. Requires standardization } \\
\text { and further study for use as a management tool. }\end{array}$ \\
\hline $\begin{array}{l}\text { Quantitative hepatitis B } \\
\text { viral DNA }\end{array}$ & Hepatitis B viral genetic material & $\begin{array}{l}\text { HBV viral load, ALT, and HBeAg status together } \\
\text { with fibrosis state establish treatment } \\
\text { initiation and procedures. qHBV DNA is used to } \\
\text { monitor and manage therapy and post-therapy } \\
\text { and predict cirrhosis and HCC development. }\end{array}$ \\
\hline $\begin{array}{l}\text { Hepatitis B virus } \\
\text { resistance mutations } \\
\text { (HBV polymerase } \\
\text { gene) }\end{array}$ & $\begin{array}{l}\text { Mutations in the HBV polymerase } \\
\text { associated with resistance to: LAM } \\
\text { (L80V/I, V173L, L180M, A181T/V, } \\
\text { M204V/I); ADV (A181T/V, N236T); ETV } \\
\text { (T184S/A/I/L/G/C/M, S202C/G/I, } \\
\text { M250I/V); and TDFc (A181T/N, N236T) }\end{array}$ & $\begin{array}{l}\text { Select/modify appropriate treatment in patients } \\
\text { who have been treated previously or in those } \\
\text { who are not responding to treatment }\end{array}$ \\
\hline $\begin{array}{l}\text { Basal core promoter } \\
(B C P) \text { and precore } \\
(P C) \text { gene region } \\
\text { mutations }\end{array}$ & $\begin{array}{l}\text { The most common basal core promoter } \\
\text { mutation, } \mathrm{A} 1762 \mathrm{~T} / \mathrm{G} 1764 \mathrm{~A} \text {, and the } \\
\text { precore stop codon mutation, } \mathrm{G} 1896 \mathrm{~A}\end{array}$ & $\begin{array}{l}\text { These mutations may influence immune response } \\
\text { and disease outcome. G1896A and } \\
\text { A1762T/G1764A abolish and reduce expression } \\
\text { of HBeAg, respectively. Both mutations are } \\
\text { associated with different HBV genotypes, and } \\
\text { A1762T/G1764A is significantly associated } \\
\text { with an increased HCC risk. }\end{array}$ \\
\hline
\end{tabular}


Table 2. (Continued)

\begin{tabular}{|c|c|c|}
\hline Test $^{\mathrm{a}}$ & Detection target & Interpretation and comments \\
\hline HBV genotyping & $\begin{array}{l}\text { Complete } \mathrm{HBV} \text { genome or the } \mathrm{HBsAg} \\
\text { coding region }\end{array}$ & $\begin{array}{l}\text { Identify HBV genotype (A-H) for ep } \\
\text { and prognostic purposes. Certain } \\
\text { genotypes have been shown to re } \\
\text { to PEG-IFN therapy or to be assoc } \\
\text { more severe disease outcomes. }\end{array}$ \\
\hline
\end{tabular}

between "target not detected" (TND) and " $<6.0 \mathrm{IU} / \mathrm{mL}$ " upon duplicate testing (data not published). The cost of these assays is substantial, and as a result, samples are rarely duplicate tested; therefore, quantification results close to the LoD should be interpreted with caution. Despite an observed high correlation between Roche and Abbott HBV DNA quantification assays, discrepancies have been described in patients undergoing antiviral therapy, such that 25/134 (18.7 \%) NA-treated patients had no detectable HBV DNA by the Roche assay but were persistently positive with the Abbott test $[27,28]$. These differences may be indirectly associated with the effect of long-term NA therapy and selective pressures upon the viral genome [29]. We have also observed discrepancies in the HBV DNA level, especially in samples having $<6.0 \mathrm{IU} / \mathrm{mL}$ as detected by the Roche Cobas High Pure/Cobas TaqMan assay, and were able to link these differences directly to nucleotide variation within the region of the reverse primer used in the quantification assay (data not published) [30].

Management guidelines do specify that "assays of lower sensitivity are not recommended" for monitoring during therapy; however, it is unknown whether use of "more" sensitive HBV DNA assays would be clinically relevant. A correlation between the level of HBV DNA at the time of treatment cessation, based on the limit of detection of the assay used in the study, and the risk for relapse has not been fully investigated. However, it is clear that relapse rates remain highly variable after controlling for differing definitions of virological relapse and viral load LoDs defining undetectable DNA [31]. For example, studies by Chi et al. and Seto et al., investigating HBeAg-negative patients discontinuing NA therapy, used $<200$ and $<20 \mathrm{IU} / \mathrm{mL}$, respectively, as the definition of undetectable DNA. Chi et al. observed $54 \%$ of patients to relapse after 1 year, while Seto et al. observed $91.4 \%$ of patients to relapse within 48 weeks $[32 \bullet \bullet, 33]$. The variation observed in these and numerous other studies, all of which followed suggested management guideline endpoints, illustrates the lack of association between an undetectable HBV DNA IU/mL value and risk of relapse. However, differences in study design and population, duration of therapy or consolidation, and different endpoint definitions likely contribute to the variability observed [31]. 


\section{Role of residual HBV DNA at treatment cessation}

Despite this lack of association, the clinical relevance of minimal residual viremia at the time of treatment cessation and during off-treatment follow-up is still a question of interest. Few studies have looked at viral rebound after NA treatment achieved HBV DNA inhibition below the PCR LoD, defined as TND or $<10 \mathrm{IU} / \mathrm{mL}$ by the most sensitive assays. Undetectable HBV DNA in Chinese NA-treated patients was investigated in a retrospective study, which re-analyzed samples using a highly sensitive PCR assay and reported residual HBV viremia in $41.7 \%$ with a significantly higher detectable rate and mean level of HBV DNA in the relapse group compared to the non-relapse group [34]. Another study involving 120 Chinese patients receiving ETV treatment reported a similar rate of residual HBV viremia-34.2\% [35]. Contrary to these studies, residual HBV viremia was present in $94 \%$ of German patients who were previously presumed to have undetectable HBV DNA (LoD 60-80 IU/mL) after NA treatment. Upon re-testing the samples with a sensitive real-time PCR ( $\mathrm{LoD}<10 \mathrm{IU} / \mathrm{mL}$; Abbott), continuously detectable residual HBV DNA was demonstrated in one third of the patients in all samples throughout the treatment (11-111 months), while the rest had complete suppression of the viral replication in at least one of several consecutive samples [36]. It should be noted that while the majority of the samples were positive with values lower than the LoD of the previous PCR assay, some had values well above that LoD. The median residual viremia levels among HBeAg-positive and HBeAgnegative patients were 16 (1-197) and 9 (1-549) IU/mL, respectively. Although such discrepancies are not unusual considering the expected higher variation with minimal residual viremia, this makes it more difficult to determine which marginal level of virus replication may be associated with viral rebound or sustained response. Considering the lack of association with HBV DNA levels $(<200 \mathrm{IU} / \mathrm{mL})$ and relapse as described earlier, further residual DNA studies with larger patient populations will be needed to confirm this finding or determine what role trace HBV DNA has in virological relapse.

\section{Quantitative HBsAg monitoring of treatment response to Peg-IFN}

Standardized qHBsAg assays have only recently become commercially available (Table 2), and they cannot distinguish between the different forms of HBsAg produced either virion associated, subviral forms or produced from integrated sequences $[37,38]$. Serum qHBsAg appears to be more strongly correlated with intrahepatic HBV covalently closed circular DNA (cccDNA) levels in HBeAgpositive patients compared to HBeAg-negative patients. This is possibly due to more viral integration events as well as the presence of more virus-associated HBsAg in highly viremic HBeAg-positive patients. Our studies and others have shown that the qHBsAg varies with HBV genotype and with CHB disease phase [39-41]. The levels are highest in the immune tolerance phase, with a decline during the immune clearance phase and a slow progressive decrease after HBeAg seroconversion $[42,43 \bullet \bullet]$. Recent studies suggest that a single $\mathrm{qHBsAg}$ measurement $(<1000 \mathrm{IU} / \mathrm{mL})$ along with HBV DNA $<2000 \mathrm{IU} / \mathrm{mL}$ is predictive for maintenance of inactive carrier status and risk of reactivation (96\% positive predictive value), reflecting improved host immune control of HBV infection (Table 3) [44]. 


\begin{tabular}{|c|c|c|c|}
\hline Disease phase & $\begin{array}{l}\text { Expected baseline } \\
\text { range } \\
\log _{10} \mathrm{IU} / \mathrm{mL}\end{array}$ & $\begin{array}{l}\text { Annual decline } \\
\log _{10} \mathrm{IU} / \mathrm{mL} \text { (ethnicity) }\end{array}$ & Comments \\
\hline $\begin{array}{l}\text { Inactive } \\
\qquad(\mathrm{HBV} \text { DNA is }<2000 \mathrm{IU} / \mathrm{mL})\end{array}$ & $1.5-3.0$ & 0.043-0.077 (Asian) & $\begin{array}{l}\text { 3.3 } \log _{10} \text { (i.e., } \\
1000-<2000 \mathrm{IU} / \mathrm{mL} \text { inactive, } \\
\text { Mediterranean/European) } \\
\text { 1.69-2 } \log _{10} \text { (i.e., } \\
<50-100 \mathrm{IU} / \mathrm{mL} \text { in Asians) } \\
\text { predicts HBsAg loss at } 6 \text { years }\end{array}$ \\
\hline Immune-tolerant & $4.5-5.0$ & 0.006 (Asian) & $\begin{array}{l}\text { } 5 \log _{10} \text { (i.e., } \\
>100,000 \mathrm{IU} / \mathrm{mL} \text { ) indicates } \\
\text { immune tolerance. Can be } \\
\text { used to differentiate } \\
\text { immune clearance if HBV } \\
\text { DNA is high and ALT is } \\
\text { minimally elevated. }\end{array}$ \\
\hline HBeAg-negative/reactivation & $\sim 3.0$ & - & $\begin{array}{l}\text { Lower baseline HBsAg predicts } \\
\text { decline and loss. Higher } \\
\text { baseline level predicts } \\
\text { HBeAg-negative hepatitis } \\
\text { flare. }\end{array}$ \\
\hline NA-treated & $\begin{array}{l}<2 \log _{10} \\
(100-1000 \mathrm{IU} / \mathrm{mL} \\
\text { lower risk of relapse } \\
\text { after NA stopped } \\
\text { (Asians) }\end{array}$ & $\begin{array}{l}\text { Decline }>0.5 \log _{10} \text { in } 2 \text { years } \\
\text { after achieve HBV DNA } \\
\text { suppression assoc. HBsAg } \\
\text { loss (Western European) or } \\
0.166 \log _{10} \mathrm{IU} / \mathrm{mL} / \text { year } \\
\text { (Asian) }\end{array}$ & $\begin{array}{l}\text { Rapid decline }>1 \log _{10} \text { after } \\
1 \text { year predicts } \mathrm{HBsAg} \text { loss. } \\
\text { Limited effect on } \mathrm{qHBsAg}\end{array}$ \\
\hline $\begin{array}{l}\text { Peg-IFN } \\
12 \text { week stopping rules }\end{array}$ & $\begin{array}{l}\text { HBeAg-positive: } \\
\text { - Week } 12 \mathrm{HBsAg}>20 \mathrm{C} \\
\mathrm{IU} / \mathrm{mL}\left(\sim 4.3 \log _{10}\right)=\mathrm{r} \\
\text { - Week } 12<300 \mathrm{IU} / \mathrm{mL} \\
\text { predicts SVR } \\
\text { - Week } 24 \text { non-respond } \\
\text { and }<2 \text { log drop in HB } \\
\text { HBeAg-negative: } \\
\text { - Week } 12 \text { decline }>0.5 \\
\text { - Week } 12 \text { decline }+2 \mathrm{l} \\
\text { - <10 IU/mL at week } 4\end{array}$ & $\begin{array}{l}\text { response (Asians) } \\
24<1500 \mathrm{IU} / \mathrm{mL}\left(3.1 \log _{10}\right) \\
\text { f no HBsAg decline from baseline } \\
\text { NAenotype D) } \\
\text { rop HBV DNA } \sim 40 \% \text { develop SVR } \\
\text { redicted HBsAg loss }\end{array}$ & $\begin{array}{l}\text { HBsAg decline on } \mathrm{Rx} \text { is } \\
\text { genotype-specific } \mathrm{A}>\mathrm{B}, \mathrm{D}> \\
\mathrm{C}, \mathrm{E} \text {. } \\
\text { In } \mathrm{HBeAg} \text {-negative } \mathrm{CHB} \text {, } \\
\text { qHBsAg may be used to } \\
\text { help predict response. }\end{array}$ \\
\hline
\end{tabular}

qHBsAg may vary in individual patients and require serial monitoring. The qHBsAg should be used together with HBV DNA for interpretation of results. Published data include studies with genotype A (Africans, North America, European, HIV, IDU); genotypes B, C (Asian); genotype D (Mediterranean and Eastern Europe); and genotype $\mathrm{E}$ (Africans). The published data on immune-active qHBsAg levels are very variable and are not included

Expert management guidelines for CHB recommend that Peg-IFN be considered a first option for treatment in selected patients due to the advantages of a finite duration of therapy and the greater likelihood of durable HBeAg and HBsAg seroconversions [21, 45]. In HBeAg-positive patients, a standard duration of a 48-week therapy induces approximately $\geq 30 \%$ HBeAg seroconversion, while the same course of therapy is 
recommended in HBeAg-negative patients having independent predictors of response, such as younger age and female gender [46, 47]. As Peg-IFN treatment is also associated with adverse effects, other predictors of response, such as HBV genotype and pre-treatment HBV DNA and ALT levels, have been developed to help select those patients best suited for Peg-IFN treatment [48-50]. Based on this data, a useful Peg-IFN HBV treatment index to predict an SVR has been developed (www.liver-GI.nl/peg-IFN) [50].

HBV genotype determination is also an important aspect of Peg-IFN treatment response prediction and all management guidelines recommend HBV genotyping among patients being considered for IFN therapy, yet many jurisdictions do not offer this service $[7 \bullet, 21,22]$. The ten HBV genotypes (A-J) have a distinct geographic distribution and the natural history of each genotype contributes to the major transmission mode and associated endemicity often observed in different regions of the world [51]. A map showing the global geographical distribution of HBV genotypes is shown in Fig. 1. Genotype A was demonstrated to be an independent risk factor for the progression to chronic infection following transmission and acute infection, possibly due to the increased transmission rate and persistent viremia that has been described for genotype A [52-54]. Despite increased chronicity among genotype A-infected individuals, genotype A is associated with an increased likelihood of HBsAg seroclearance compared to other genotypes, particularly in patients treated with Peg-IFN [50]. Similarly, genotype B-infected individuals have demonstrated a higher likelihood of stable HBsAg seroclearance compared to genotype C-infected patients [55].

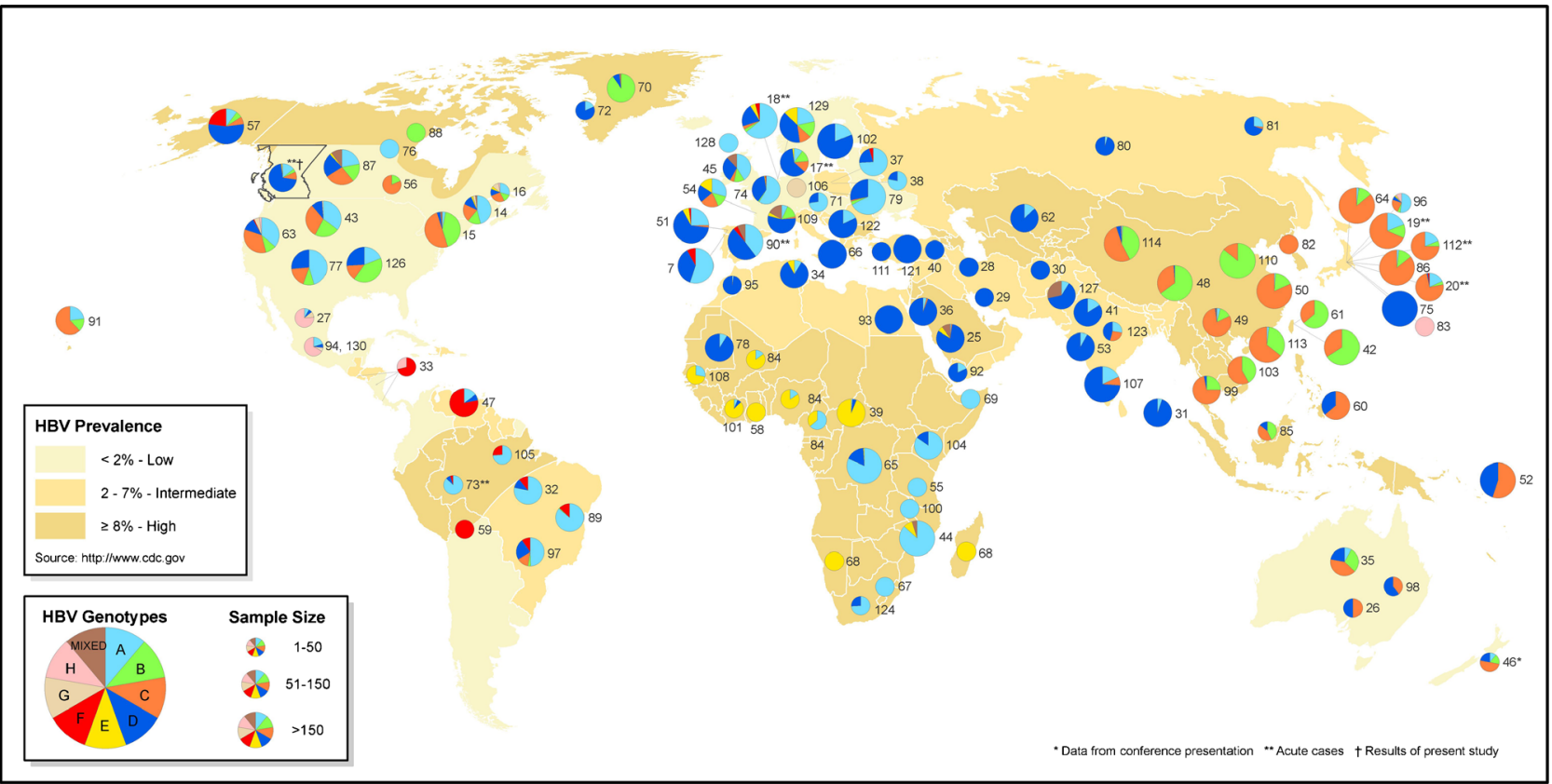

Fig. 1. Global geographical distribution of HBV genotypes. The map of genotype distribution and prevalence was determined through literature review and published in a previous study of acute hepatitis B infection in British Columbia, Canada [99]. The figure is reproduced with permission from John Wiley and Sons. 
Quantitative HBsAg levels have recently been shown to provide an accurate prediction of response to Peg-IFN. Baseline qHBsAg levels $<20,000 \mathrm{IU} / \mathrm{mL}$ have been correlated with achievement of SVR at 6 months post-treatment [56]. The decline in qHBsAg is particularly useful as an on-treatment biomarker and negative predictive stopping rule [57]. Thus, a lack of qHBsAg decline by week 12 and a $<2-\log _{10}$ decline in HBV DNA indicates subsequent non-response (95-100\% negative predictive value) in both HBeAg-positive and HBeAg-negative patients (Table 3) [58-60]. A proposed algorithm for using qHBsAg to guide response to Peg-IFN treatment is provided (Fig. 2a).

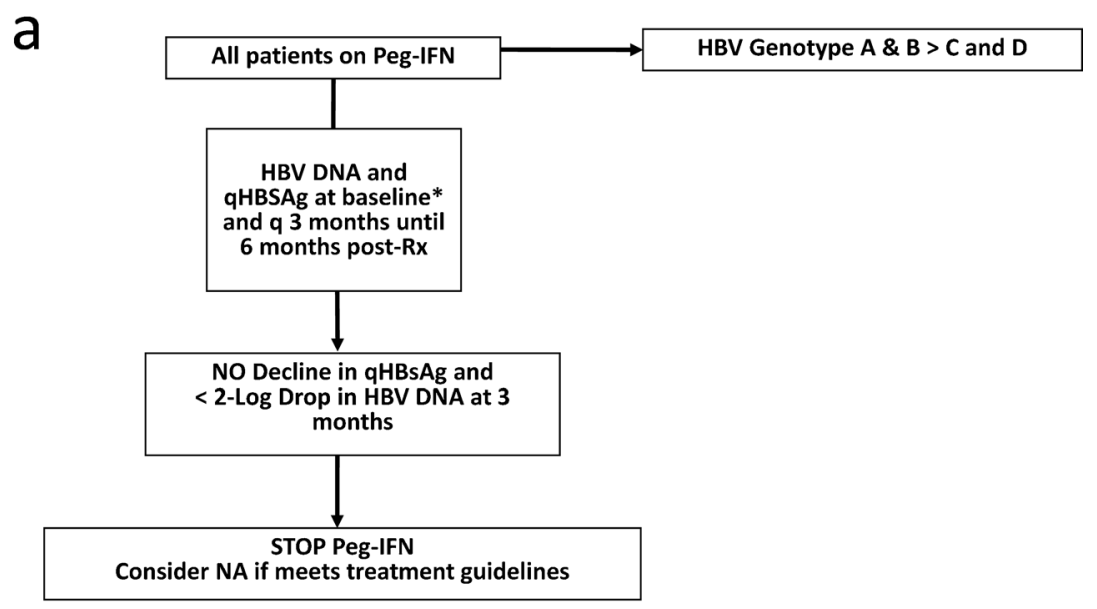

${ }^{*} \mathrm{qHBsAg}>20,000 \mathrm{IU} / \mathrm{ml}$ poor predictive response for treatment. A Peg-IFN treatment calculator has been proposed to predict chance of response in HBeAg positive patients (www.liver-GI.nl/peg-IFN).

b

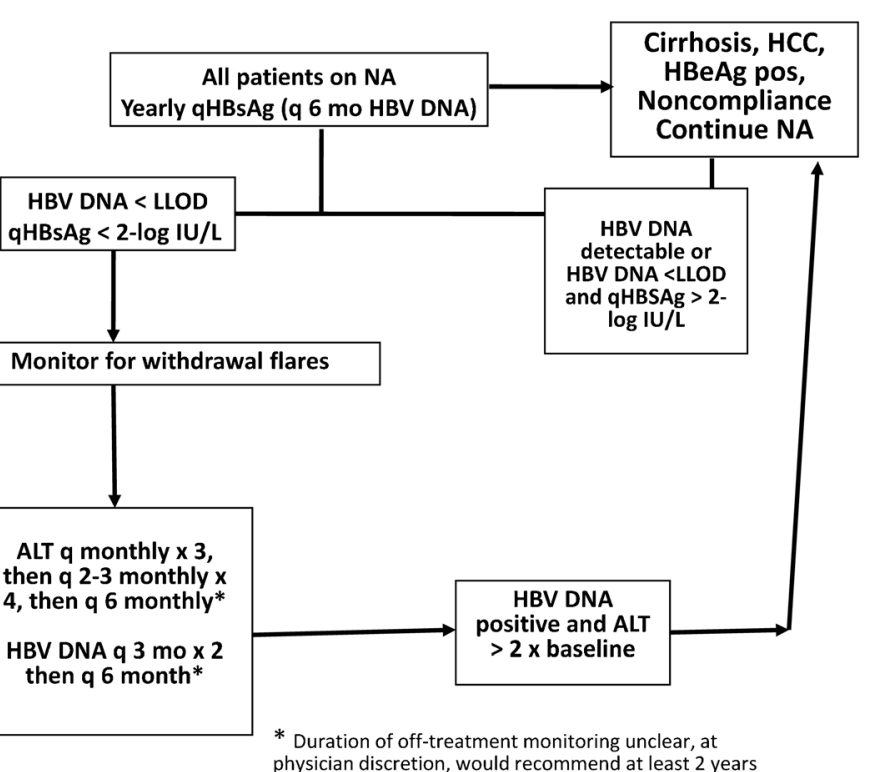

Fig. 2. a Proposed clinical algorithm for qHBsAg monitoring during Peg-IFN therapy and early stopping rule at 12 weeks for prediction of a sustained virologic response ( $q$ quantify). $\mathbf{b}$ Proposed clinical algorithm for cessation of long-term NA therapy based on qHBsAg monitoring and HBV DNA testing according to a sensitive clinical PCR assay ( $q$ quantify). 


\section{Quantitative HBsAg monitoring of treatment response to NAs}

Oral NAs directly inhibit HBV reverse transcriptase activity during infection and so have the advantage of rapidly reducing $\mathrm{HBV}$ replication resulting in reduced HBV DNA levels and normalization of serum ALT. Current management guidelines recommend either ETV or TDF as an initial therapy for the treatment of naïve patients due to their potency and high genetic barrier to resistance [21, 22, 61]. NA treatments are not considered to readily "cure" or eradicate HBV infection, due to the persistence of the HBV replication cycle intermediate, cccDNA, which is not targeted by NAs [62]. Long-term or indefinite treatment is recommended in order to reach secondary endpoints, such as HBeAg seroconversion and undetectable HBV DNA, at which time treatment cessation may be considered (Table 1).

A more rapid HBsAg decline in the first year after starting NA or a reduction rate of $>0.166 \log _{10} \mathrm{IU} / \mathrm{mL} /$ year may predict subsequent HBsAg loss [63]. In studies involving Asian patients, a qHBsAg level $<2 \log _{10} \mathrm{IU} / \mathrm{mL}$ predicted lower risk of increased virological and biochemical responses after stopping NA therapy with $93 \%$ probability of achieving an off-treatment SVR [38, 64-66]. In European patients, with HBV genotype D infection, qHBsAg titres < 1000 IU/ $\mathrm{mL}$ could predict remission and a subsequent HBsAg loss [67]. Although differences in inclusion criteria limited comparison across studies, NA-treated HBeAg-positive patients show greater qHBsAg decline compared to HBeAgnegative patients, especially with higher baseline ALT levels [68]. As noted in our studies and others, there are genotype-specific differences in HBsAg kinetics in response to NA therapy; thus, more studies in regions with a multiethnic genotype distribution, such as Canada, are needed to confirm the results of Asian studies [39, 41, 69]. Further long-term prospective evaluation is also needed regarding the impact of baseline HBsAg levels and the kinetics of qHBsAg decline in identifying patients who will have a durable off-treatment NA response. A proposed algorithm for using qHBsAg to guide response to NAs is provided (Fig. 2 b).

\section{Discontinuation of NA therapy: rules}

Understanding the factors necessary for an enduring clinical response to allow the discontinuation of NA treatment is critical, as lifelong therapy has potential drawbacks, such as maintaining compliance and ongoing financial costs $[65,70]$. In order for treatment cessation to be considered, defined stopping rules have been suggested based on clinical studies over the past several years. It is agreed that patients having decompensated cirrhosis, regardless of HBeAg status, are excluded from finite treatment options, due to the risk of liver failure if virological rebound occurs $[7 \bullet]$.

Studies involving ETV and TDF have contributed to current recommendations guiding NA treatment cessation in HBeAg-positive patients. Treatment discontinuation is suggested for those patients achieving HBeAg seroconversion together with sustained undetectable HBV DNA, based on two consecutive measurements at least 6 months apart, and ALT normalization following at least 1 year but preferably 3 years of consolidation therapy $[71,72 \bullet$. Extended consolidation $(>3$ years) provided a substantially lower relapse rate compared to <1-year 
consolidation for both HBeAg-positive (25 vs. $54 \% ; P=0.063$ ) and

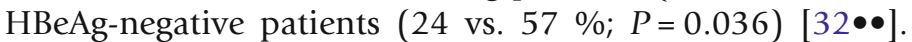

The HBeAg-negative patient population does not have a specific endpoint for treatment cessation; thus, most management guidelines recommend lifelong treatment, until sustained HBsAg loss or seroconversion is achieved [21, 22, 61]. However, the Asian-Pacific Association for the Study of the Liver (APASL) guidelines have suggested that discontinuation of treatment may be considered in HBeAg-negative patients, following at least 2 years treatment and having documented undetectable HBV DNA $(<12 \mathrm{IU} / \mathrm{mL})$ on 3 separate occasions at least 6 months apart [72•]. Similarly, other associations acknowledge that undetectable HBV DNA (based on a sensitive PCR assay) and ALT normalization may be considered practical measures of response in HBeAg-negative patients [61]. Indeed, undetectable HBV DNA is achievable in a larger percentage of HBeAg-negative patients compared to HBeAg-positive patients, largely due to their lower baseline DNA levels [73]. However, studies that followed APASL guidelines for HBeAgnegative treatment cessation describe high rates $(>80 \%)$ of virologic relapse within 48 weeks post-ETV treatment [33, 74]. In such cases, early virological relapse characterized by low HBV DNA levels $(<2000 \mathrm{IU} / \mathrm{mL})$ in the absence of a marked ALT flare may be an acceptable or even desirable scenario, allowing for host immune control to suppress viral replication instead of immediately initiating rescue therapy $[75,76 \bullet \bullet]$.

Novel virological/serological tests for monitoring treatment response

Aside from qHBsAg, there is much interest and urgency in finding more effective tools to predict treatment response prior to and during treatment, particularly for NAs. Other non-invasive serological markers, such as HBV core-related antigen (HBcrAg) and quantitative anti-HBc (qAnti-HBc), have been investigated for their utility in monitoring the natural history of infection and response to treatment (Table 2). Both biomarkers hold promise for predictive therapeutic management.

A chemiluminescent enzyme immunoassay for quantitative measurement of HBcrAg in serum (Lumipulse G HBcrAg, Fujirebio, Gent, Belgium), which detects core antigen associated with circulating viral particles, as well as denatured HBeAg and the p22 core-related protein, following detergent pre-treatment, provides a surrogate measure of the level of transcription and translation of the precore/core coding region within hepatocytes $[77,78]$. This is reflected in the positive correlation between HBcrAg and HBV DNA levels in HBeAg-negative inactive patients and with cccDNA levels [79-81]. In this regard, increasing HBcrAg levels over time have been shown to be an independent risk factor for developing HCC [82]. Several studies have demonstrated a risk of relapse following NA treatment withdrawal with HBcrAg levels >3.4-3.7 $\log _{10} \mathrm{U} / \mathrm{mL}$, such that lower HBcrAg levels either before treatment initiation or at the end of treatment correlated with therapeutic response $[83-86,87 \bullet]$. As absolute HBcrAg levels are reduced in the presence of precore or basal core promoter mutants due to eradication of HBeAg expression, supplementary mutation testing of patients may be required 
to fully understand individual patient results and ultimately for HBcrAg to be used as a management tool $[81,86]$. Although several studies have shown a moderate correlation between HBcrAg and qHBsAg levels, one study has shown a greater negative predictive likelihood with week 12 HBcrAg values $\left(>8.0 \log _{10} \mathrm{U} / \mathrm{mL}\right)$ as compared to week $12 \mathrm{qHBsAg}$ levels $\left(>4.3 \log _{10} \mathrm{U} / \mathrm{mL}\right)$ at 94.4 and $80.0 \%$, respectively, for predicting response to Peg-IFN treatment [79-81]. Thus, monitoring of HBcrAg levels may offer a more robust predictor of virological response during therapy and potential development of HCC.

Quantitative anti-HBc levels can be measured using a commercially available immunoassay (Wantai, Beijing, China) and have been found to be a sensitive and specific indicator of the host immune response. Anti$\mathrm{HBC}$ production is significantly higher during the immune clearance phase and during HBeAg-negative active infection, as compared to the immune tolerant or low replicative phases of infection. Similarly, qAnti$\mathrm{HBC}$ levels are significantly associated with liver enzyme levels during the immune clearance phase [88-90]. Several studies have investigated the utility of baseline qAnti-HBc to predict response to treatment. In studies of patients treated with Peg-IFN, patients who seroconverted from HBeAg positivity to anti-HBe positivity, following end of treatment or follow-up, had significantly higher levels of qAnti-HBc at baseline. Furthermore, qAnti-HBc levels at baseline were considered to be the best independent predictor of HBeAg seroconversion following either Peg-IFN or telbivudine/ADV treatments compared to the baseline predictive value of ALT or HBV DNA levels, with a predictive threshold value of qAnti$\mathrm{HBC}$ at baseline proposed $\left(\geq 4.4-4.5 \log _{10} \mathrm{IU} / \mathrm{mL}\right)$ [91, 92]. Using qAnti$\mathrm{HBC}$ as a surrogate marker of the overall immune response may allow for more effective prediction of achieving response to therapy and has been shown to be independent of HBV genotype, unlike qHBsAg, and to have a longer half-life in serum, as compared to ALT [90, 93].

\section{Conclusions}

Over the past decade, clinical studies and research investigations have provided an improved understanding of how best to use current antiviral therapies for HBV. However, until new treatments are developed for novel targets associated with HBV infection, such as cccDNA, host immune effectors, modified direct-acting antivirals, or viral entry, assembly or secretion inhibitors, management of patients on current antiviral therapies will continue to require careful monitoring and laboratory testing [94-98]. The virological monitoring tests, including HBV serological markers, quantitative HBV DNA, and qHBsAg, continue to improve in terms of sensitivity and linear range. Highly sensitive HBV DNA assays should be used to determine the association and level of residual viremia with relapse, and whether a TND quantification result is essential for complete suppression of viral replication and SVR. Increasing data from clinical studies indicate that both HBV genotyping and qHBsAg monitoring may not be available in most clinical diagnostic labs yet may be useful for predicting CHB natural history and monitoring on-treatment response, and hence, should be available to 
expert providers. Potential serological markers under development offer the prospect of increased predictive value for treatment response and will complement present monitoring methods.

\section{Compliance with Ethical Standards}

Conflict of Interest

Dr. Carla Osiowy declares that she has no conflict of interest.

Dr. Carla Coffin declares that she has no conflict of interest.

Dr. Anton Andonov declares that he has no conflict of interest.

\section{Human and Animal Rights and Informed Consent}

This article does not contain any studies with human or animal subjects performed by any of the authors.

Open Access This article is distributed under the terms of the Creative Commons Attribution 4.0 International License (http://creativecommons.org/licenses/by/4.0/), which permits unrestricted use, distribution, and reproduction in any medium, provided you give appropriate credit to the original author(s) and the source, provide a link to the Creative Commons license, and indicate if changes were made.

\section{References and Recommended Reading}

Papers of particular interest, published recently, have been

highlighted as:

- Of importance

-• Of major importance

1. Schweitzer A, Horn J, Mikolajczyk R, Krause G, Ott JJ. Estimations of worldwide prevalence of chronic hepatitis B virus infection: a systemic review of data published between 1965 and 2013. Lancet. 2015;386:1546-55.

2. Osiowy C, Giles E, Trubnikov M, Choudhri Y, Andonov A. Characterization of acute and chronic hepatitis B virus genotypes in Canada. PLoS One. 2015; 10:e0136074.

3. Devi U, Locarnini S. Hepatitis B antivirals and resistance. Curr Opin Virol. 2013;3:495-500.

4. Marotta P, Lucas K. Management of hepatitis B: a longitudinal national survey-impact of the Canadian hepatitis B consensus guidelines. Can J Gastroenterol. 2010;24:537-42.

5. Sherman M, Lee SS. Canadian patients with chronic hepatitis B cannot access appropriate drug treatments: a call for change. Can J Gastroenterol. 2011;25:538-41

6. Wong T, Jepson G. Canada's provincial drug formulary system. Regulatory focus 2011:19-20.

7.• Terrault N, Bzowej N, Chang K, Hwang J, Jonas M, Murad MH. AASLD guidelines for treatment of chronic hepatitis B. Hepatology. 2016;63:261-83.
This guideline provides the most up-to-date official recommendations for treatment of chronic hepatitis by the American Association for the Study of Liver Diseases (AASLD).

8. Yuen M, Ahn SH, Chen D, Chen P, Dusheiko G, Hou J, et al. Chronic hepatitis B virus infection: disease revisit and management recommendations. J Clin Gastroenterol. 2016;50:286-94.

9. Chang T, Liaw YF, Wu S, Schiff ER, Han KH, Lai CL, et al. Long-term entecavir therapy results in the reversal of fibrosis/cirrhosis and continued histological improvement in patients with chronic hepatitis B. Hepatology. 2010;52:886-93.

10. Marcellin P, Gane E, Buti M, Afdhal N, Sievert W, Jacobson I, et al. Regression of cirrhosis during treatment with tenofovir disoproxil fumarate for chronic hepatitis B: a 5-year open-label follow-up study. Lancet. 2013;381:468-75.

11. Reijnders JGP, Rijckborst V, Sonneveld MJ, Scherbeijn S, Boucher C, Hansen B, et al. Kinetics of hepatitis B surface antigen differ between treatment with peginterferon and entecavir. J Hepatol. 2011;54:449-54.

12. Martinot-Peignoux M, Marcellin P. Virological and serological tools to optimize the management of patients with chronic hepatitis B. Liver Int. 2016;36(S1):78-84. 
This review provides a comprehensive overview of how to use quantitative laboratory testing (qHBsAg and DNA) to manage treatment of chronic hepatitis B patients.

13. Iloeje UH, Yang H, Chen CJ. Natural history of chronic hepatitis B: what exactly has REVEAL revealed? Liver Int. 2012;32:1333-41.

14. Buti M, Fung S, Gane E, Afdhal N, Flisiak R, Gurel S, et al. Long-term clinical outcomes in cirrhotic chronic hepatitis B patients treated with tenofovir disoproxil fumarate for up to 5 years. Hepatol Int. 2015;9:24350.

15. Pavšič J, Žel J, Milavec M. Assessment of the real-time PCR and different digital PCR platforms for DNA quantification. Anal Bioanal Chem. 2016;408:107-21.

16. Liu Y, Yao C. Rapid and quantitative detection of hepatitis B. World J Gastroenterol. 2015;21:11954-63.

17. Saldanha J, Gerlich W, Lelie N, Dawson P, Heermann $\mathrm{K}$, Heath A, et al. An international collaborative study to establish a World Health Organization international standard for hepatitis B virus DNA nucleic acid amplification techniques. Vox Sang. 2001;80:63-71.

18. Hollinger FB, Sood G. Occult hepatitis B virus infection: a covert operation. J Viral Hepatitis. 2010;17:1-15.

19. Pawlotsky J, Dusheiko G, Hatzakis A, Lau D, Lau G, Liang TJ, et al. Virologic monitoring of hepatitis $B$ virus therapy in clinical trials and practice: recommendations for a standardized approach. Gastroenterology. 2008;134:405-15.

20. Andersson KL, Chung RT. Monitoring during and after antiviral therapy for hepatitis B. Hepatology. 2009;49:S166-73.

21. Coffin CS, Fung S, Ma MM. Management of chronic hepatitis B: Canadian Association for the Study of the Liver consensus guidelines. Can J Gastroenterol. 2012;26:917-38.

22. European Association for the Study of the Liver. EASL clinical practice guidelines: management of chronic hepatitis B virus infection. J Hepatol. 2012;57:167-85.

23.• Papatheodoridis G, Vlachogiannokos I, Cholongitas E, Wursthorn K, Thomadakis C, Touloumi G, et al. Discontinuation of oral antivirals in chronic hepatitis B: a systematic review. Hepatology. 2016;63:1481-92.

This systematic review evaluates NA treatment studies to show discontinuation may lead to durable virological remission in a substantial proportion of HBeAg-negative and -positive patients, with specific factors shown to be predictive for remission.

24. Villar L, Cruz H, Barbosa J, Bezerra C, Portilho M, Scalioni L. Update on hepatitis B and C virus diagnosis. World J Virol. 2015;4:323-42.

25. Bessone F. Re-appraisal of old and new diagnostic tools in the current management of chronic hepatitis B. Liver Int. 2014;34:991-1000.

26. Chevaliez S, Bouvier-Alias M, Laperche S, Hézode C, Pawlotsky J. Performance of version 2.0 of the Cobas Ampliprep/Cobas TaqMan real-time PCR assay for hepatitis B virus DNA quantification. J Clin Microbiol. 2010;48:3641-7.

27. Wursthorn K, Jaroszewicz J, Zacher B, Darnedde M, Raupach R, Mederacke I, et al. Correlation between the Elecsys HBsAg II assay and the Architect assay for the quantification of hepatitis B surface antigen (HBsAg) in the serum. J Clin Virol. 2011;50:292-6.

28. Yeh M, Huang C, Huang C, Liu S, Yang H, Hsieh M, et al. Abbott RealTime HBV assay is more sensitive in detection of low viral load and little impacted by drug resistant mutation in chronic hepatitis $\mathrm{B}$ patients under nucleos(t)ide analogues therapy. PLoS One. 2014;9:e101790.

29. Homs M, Caballero A, Gregori J, Tabernero D, Quer J, Nieto L, et al. Clinical application of estimating hepatitis B virus quasispecies complexity by massive sequencing: correlation between natural evolution and on-treatment evolution. PLoS One. 2014;9:e112306.

30. Andonov A, Osiowy C, Borlang J. Diagnostic algorithm for the detection of low level HBV DNA by PCR. Vox Sang. 2014;107:S15.

31. Kranidioti H, Manolakopoulos S, Khakoo SI. Outcome after discontinuation of nucleot(s)ide analogues in chronic hepatitis B: relapse rate and associated factors. Ann Gastroenterol. 2015;28:173-81.

32.• Chi H, Hansen B, Yim C, Arends P, Abu-Amara M, van der Eijk A, et al. Reduced risk of relapse after long-term nucleos(t)ide analogue consolidation therapy for chronic hepatitis B. Aliment Pharmacol Ther. 2015;41:867-76.

This study describes the importance of prolonged consolidation therapy for both HBeAg-negative and -positive patients in decreasing the risk of persistent virological relapse and increasing the likelihood of HBsAg loss upon NA cessation.

33. Seto W, Hui A, Wong V, Wong G, Liu K, Lai C, et al. Treatment cessation of entecavir in Asian patients with hepatitis $\mathrm{B}$ e antigen negative chronic hepatitis $\mathrm{B}$ : a multicentre prospective study. Gut. 2015;64:667-72.

34. Jiang J, Huang Z, He L, Huang Y, Su M, Xie R, et al. Residual amount of HBV DNA in serum is related to relapse in chronic hepatitis $\mathrm{B}$ patients after cessation of nucleos(t)ide analogs. J Clin Gastroenterol. 2015;49:323-8.

35. Shi M, Sun W, Hua Y, Han B, Shi L. Effects of entecavir on hepatitis B virus covalently closed circular DNA in hepatitis B e antigen-positive patients with hepatitis B. PLoS One. 2015;10:e0117741.

36. Maier M, Liebert U, Wittekind C, Kaiser T, Berg T, Wiegand J. Clinical relevance of minimal residual viremia during long-term therapy with nucleos(t)ide analogues in patients with chronic hepatitis B. PLoS One. 2013;8:e67481.

37. Liaw YF. Clinical utility of hepatitis B surface antigen quantification in patients with chronic hepatitis B: a review. Hepatology. 2011;54:E1-9.

38. Chan $\mathrm{H}$, Thompson A, Martinot-Peignoux M, Piratvisuth T, Cornberg M, Brunetto M, et al. Hepatitis $B$ surface antigen quantification: why and how to use it 
in 2011-a core group report. J Hepatol.

2011;55:1121-31.

39. Congly SE, Wong P, Al-Busafi S, Doucette K, Fung S, Ghali P, et al. Characterization of hepatitis B virus genotypes and quantitative hepatitis $\mathrm{B}$ surface antigen titres in North American tertiary referral liver centres. Liver Int. 2013;33:1363-9.

40. Jaroszewicz J, Serrano B, Wursthorn K, Deterding K, Schlue J, Raupach R, et al. Hepatitis B surface antigen (HBsAg) levels in the natural history of hepatitis B virus (HBV)-infection: a European perspective. J Hepatol. 2010;52:514-22.

41. O'Neil C, Congly SE, Lee SS, Borman M, Charlton C, Osiowy $\mathrm{C}$, et al. Dynamics of serum quantitative hepatitis $\mathrm{B}$ surface antigen testing in assessing nucleos/tide analog treatment response and disease phenotype in chronic hepatitis B patients in Canada. J Hepatol. 2016;64:S356.

42. Nguyen T, Thompson A, Bowden S, Croagh C, Bell S, Desmond $\mathrm{P}$, et al. Hepatitis B surface antigen levels during the natural history of chronic hepatitis B: a perspective on Asia. J Hepatol. 2010;52:508-13.

43.• Brouwer W, Chan H, Brunetto M, Martinot-Peignoux M, Arends P, Cornberg M, et al. Repeated measurements of hepatitis B surface antigen identify carriers of inactive HBV during long-term follow-up. Clin Gastroenterol Hepatol. 2016; dx.doi.org/10.1016/j. cgh.2016.01.019.

This study determined a cutoff level of quantitative HBsAg $(<100 \mathrm{IU} / \mathrm{mL})$ that identifies HBeAg-negative patients having inactive infection with a high level of specificity, thus further improving existing prediction rules.

44. Liu J, Yang H, Le M, Jen C, Batrla-Utermann R, Lu S, et al. Serum levels of hepatitis B surface antigen and DNA can predict inactive carriers with low risk of disease progression. Hepatology. 2016; in press: DOI 10.1002/ hep. 28552.

45. Perrillo R. Benefits and risks of interferon therapy for hepatitis B. Hepatology. 2009;49:S103-11.

46. Janssen $H$, van Zonneveld M, Senturk H, Zeuzem S, Akarca US, Cakaloglu Y, et al. Pegylated interferon alfa$2 \mathrm{~b}$ alone or in combination with lamivudine for HBeAg-positive chronic hepatitis B: a randomised trial. Lancet. 2005;365:123-9.

47. Viganò M, Invernizzi F, Lampertico P. Optimal therapy of chronic hepatitis B: how do I treat my HBeAgnegative patients? Liver Int. 2015;35:S107-13.

48. Isorce N, Lucifora J, Zoulim F, Durantel D. Immunemodulators to combat hepatitis B virus infection: from IFN- $\alpha$ to novel investigational immunotherapeutic strategies. Antivir Res. 2015;122:69-81.

49. Sonneveld MJ, Rijckborst V, Cakaloglu Y, Simon K, Heathcote EJ, Tabak F, et al. Durable hepatitis B surface antigen decline in hepatitis $\mathrm{B} e$ antigen-positive chronic hepatitis B patients treated with pegylated interferonalpha2b: relation to response and HBV genotype. Antivir Ther. 2012;17:9-17.

50. Buster E, Hansen B, Lau G, Piratvisuth T, Zeuzem S, Steyerberg E, et al. Factors that predict response of patients with hepatitis $\mathrm{B}$ e antigen-positive chronic hepatitis B to peginterferon-alfa. Gastroenterology. 2009;137:2002-9.

51. Lin CL, Kao JH. Hepatitis B virus genotypes and variants. Cold Spring Harb Perspect Med. 2015;5:a021436.

52. Ito K, Yotsuyanagi $\mathrm{H}$, Yatsuhashi $\mathrm{H}$, Karino $\mathrm{Y}$, Takikawa Y, Saito T, et al. Risk factors for long-term persistence of serum hepatitis B surface antigen following acute hepatitis B virus infection in Japanese adults. Hepatology. 2014;59:89-97.

53. Ramachandran S, Purdy MA, Xia GL, Campo DS, Dimitrova Z, Teshale EH, et al. Recent population expansions of hepatitis B virus in the United States. J Virol. 2014;88:13971-80.

54. Yokoyama Y, Miyagi T, Hikita H, Yoshioka T, Mukai K, Nawa T, et al. The hepatitis B virus genotype affects the persistence of viral replication in immunodeficient NOG mice. PLoS One. 2015;10:e0144775.

55. Seto W, Tanaka Y, Wong D, Shinkai N, Cheung K, Liu $\mathrm{K}$, et al. Longitudinal profiles of highly sensitive hepatitis B surface antigen levels: re-evaluation of HBsAg seroclearance. Liver Int. 2016;36:642-50.

56. Piratvisuth T, Marcellin P, Popescu M, Kapprell H, Rothe V, Lu Z. Hepatitis B surface antigen: association with sustained response to peginterferon alfa- $2 \mathrm{a}$ in hepatitis B e antigen-positive patients. Hepatol Int. 2013;7:429-36.

57. Sonneveld MJ, Rijckborst V, Boucher C, Hansen B, Janssen $\mathrm{H}$. Prediction of sustained response to peginterferon alfa-2b for hepatitis $\mathrm{B}$ e antigen-positive chronic hepatitis B using on-treatment hepatitis B surface antigen decline. Hepatology. 2010;52:1251-7.

58. Sonneveld MJ, Hansen B, Piratvisuth T, Jia J, Zeuzem S, Gane E, et al. Response-guided peginterferon therapy in hepatitis B e antigen-positive chronic hepatitis B using serum hepatitis B surface antigen levels. Hepatology. 2013;58:872-80.

59. Marcellin P, Bonino F, Yurdaydin C, Hadziyannis SJ, Moucari R, Kapprell H, et al. Hepatitis B surface antigen levels: association with 5 -year response to peginterferon alfa-2a in hepatitis $\mathrm{B}$ e-antigen-negative patients. Hepatol Int. 2013;7:88-97.

60. Rijckborst V, Hansen B, Ferenci P, Brunetto M, Tabak F, Cakaloglu Y, et al. Validation of a stopping rule at week 12 using HBsAg and HBV DNA for HBeAg-negative patients treated with peginterferon alfa-2a. J Hepatol. 2012;56:1006-11.

61. Martin P, Lau D, Nguyen M, Janssen H, Dieterich D, Peters $\mathrm{M}$, et al. A treatment algorithm for the management of chronic hepatitis B virus infection in the United States: 2015 update. Clin Gastroenterol Hepatol. 2015;13:2071-87.

62. Nassal M. HBV cccDNA: viral persistence reservoir and key obstacle for a cure of chronic hepatitis B. Gut. 2015;64:1972-84.

63. Hosaka T, Suzuki F, Kobayashi M, Seko Y, Kawamura Y, Sezaki H, et al. Clearance of hepatitis B surface antigen during long-term nucleot(s)ide analog treatment in chronic 
hepatitis B: results from a nine-year longitudinal study. J Gastroenterol. 2013;48:930-41.

64. Cai W, Xie Q, An B, Wang H, Zhou X, Zhao G, et al. Ontreatment serum HBsAg level is predictive of sustained off-treatment virologic response to telbivudine in HBeAg-positive chronic hepatitis B patients. J Clin Virol. 2010;48:22-6.

65. Liang Y, Jiang J, Su M, Liu Z, Guo W, Huang X, et al. Predictors of relapse in chronic hepatitis $\mathrm{B}$ after discontinuation of anti-viral therapy. Aliment Pharmacol Ther. 2011;34:344-52.

66. Chen C, Chiu Y, Lu S, Lee C, Wang J, Hu T, et al. Serum hepatitis B surface antigen levels predict treatment response to nucleos(t)ide analogues. World J

Gastroenterol. 2014;20:7686-95.

67. Zoutendijk R, Hansen BE, van Vuuren AJ, Boucher C, Janssen H. Serum HBsAg decline during long-term potent nucleos(t)ide analogue therapy for chronic hepatitis B and prediction of HBsAg loss. J Infect Dis. 2011;204:415-8.

68. Tseng T, Kao JH. Clinical utility of quantitative HBsAg in natural history and nucleos(t)ide analogue treatment of chronic hepatitis B: new trick of old dog. J Gastroenterol. 2013;48:13-21.

69. Kochaksaraei S, Congly SE, Matwiy T, Castillo E, Martin $\mathrm{S}$, Charlton C, et al. Cost effectiveness of quantitative hepatitis B virus surface antigen testing in pregnancy in predicting vertical transmission risk. Liver Int. 2016; doi:10.1111/liv.13139.

70. Lim S, Aung M, Chung S, Soon C, Mak B, Lee K. Patient preferences for hepatitis $\mathrm{B}$ therapy. Antivir Ther. 2013; 18:663-70.

71. Han S, Tran T. Management of chronic hepatitis B: an overview of practice guidelines for primary care providers. J Am Board Fam Med. 2015;28:822-37.

72. Sarin S, Kumar M, Lau G, Abbas Z, Chan H, Chen C, et al. Asian-Pacific clinical practice guidelines on the management of hepatitis B: a 2015 update. Hepatol Int. 2016;10:1-98.

This guideline provides the most up-to-date official recommendations for treatment of chronic hepatitis by the AsianPacific Association for the Study of the Liver (APASL).

73. Gish R, Given B, Lai C, Locarnini S, Lau J, Lewis D, et al. Chronic hepatitis B: virology, natural history, current management and a glimpse at future opportunities. Antivir Res. 2015;121:47-58.

74. Lee I, Sun C, Su C, Wang Y, Chang H, Huang H, et al. Durability of nucleos(t)ide analogues treatment in patients with chronic hepatitis $\mathrm{B}$. Medicine.

2015;94:e1341.

75. Lampertico P. Oral antiviral therapy for HBeAg negative chronic hepatitis B: better stop or continue? Gut. 2015;64:526-8.

76.• Chang M, Liaw Y, Hadziyannis SJ. Systematic review: cessation of long-term nucleos(t)ide analogue therapy in patients with hepatitis $\mathrm{B}$ e antigen-negative chronic hepatitis B. Aliment Pharmacol Ther. 2015;42:243-57.
This systematic review evaluates NA treatment studies in HBeAg-negative patients and describes the value of careful monitoring post-NA discontinuation to allow for host immune control of viral replication to increase successful HBsAg seroclearance.

77. Rokuhara A, Tanaka E, Matsumota A, Kimura T, Yamaura T, Orii K, et al. Clinical evaluation of a new enzyme immunoassay for hepatitis B virus core-related antigen; a marker distinct from viral DNA for monitoring lamivudine treatment. J Viral Hepatitis. 2003;10:324-30.

78. Wong D, Tanaka Y, Lai C, Mizokami M, Fung J, Yuen $M$. Hepatitis B virus core-related antigens as markers for monitoring chronic hepatitis B infection. J Clin Microbiol. 2007;45:3942-7.

79. Park Y, Hong D, Shin S, Cho Y, Kim H. Performance evaluation of new automated hepatitis B viral markers in the clinical laboratory: two quantitative hepatitis B surface antigen assays and an HBV core-related antigen assay. Am J Clin Pathol. 2012;137:770-7.

80. Maasoumy B, Wiegand S, Jaroszewicz J, Bremer B, Lehmann P, Deterding K, et al. Hepatitis B core-related antigen (HBcrAg) levels in the natural history of hepatitis B virus infection in a large European cohort predominantly infected with genotypes A and D. Clin Microbiol Infect. 2015;21:606.e1-606.e10.

81. Chuaypen N, Posuwan N, Payungporn S, Tanaka Y, Shinkai N, Poovorawan Y, et al. Serum hepatitis B corerelated antigen as a treatment predictor of pegylated interferon in patients with HBeAg-positive chronic hepatitis B. Liver Int. 2016; in press: doi: 10.1111/liv. 13046.

82. Tada T, Kumada T, Toyoda H, Kiriyama S, Tanikawa M, Hisanaga Y, et al. HBcrAg predicts hepatocellular carcinoma development: an analysis using timedependent receiver operating characteristics. J Hepatol. 2016; in press: doi: 10.1016/j.jhep.2016.03.013.

83. Shinkai N, Tanaka Y, Orito E, Ito K, Ohno T, Hirashima $\mathrm{N}$, et al. Measurement of hepatitis B virus core-related antigen as predicting factor for relapse after cessation of lamivudine therapy for chronic hepatitis $B$ virus infection. Hepatol Res. 2006;36:272-6.

84. Okuhara S, Umemura T, Joshita S, Shibata S, Kimura T, Morita S, et al. Serum levels of interleukin-22 and hepatitis B core-related antigen are associated with treatment response to entecavir therapy in chronic hepatitis B. Hepatol Res. 2014;44:E172-80.

85. Matsumoto A, Tanaka E, Minami M, Okanoue T, Yatshuhashi H, Nagaoka S, et al. Low serum level of hepatitis B core-related antigen indicates unlikely reactivation of hepatitis after cessation of lamivudine therapy. Hepatol Res. 2007;37:661-6.

86. van Campenhout $M$, Brouwer W, van Oord G, Xie Q, Zhang Q, Zhang N, et al. Hepatitis B core-related antigen levels are associated with response to entecavir and peginterferon add-on therapy in HBeAg-positive chronic hepatitis B patients. Clin Microbiol Infect. 2015; in press: doi: 10.1016/j.cmi.2016.02.002. 
87.• Jung K, Park J, Chon Y, Kim H, Kang W, Kim B, et al. Clinical outcomes and predictors for relapse after cessation of oral antiviral treatment in chronic hepatitis B patients. J Gastroenterol. 2015; in press: doi:10.1007/ s00535-015-1153-1.

This study provides a recent analysis on the utility of APASL stopping rules for NA treatment of both HBeAg-negative and positive patients.

88. Yuan Q, Song L, Liu C, Li Z, Liu P, Huang C, et al. Quantitative hepatitis B core antibody level may help predict treatment response in chronic hepatitis $\mathrm{B}$ patients. Gut. 2013;62:182-4.

89. Jia W, Song L, Fang Y, Wu X, Liu D, Xu C, et al. Antibody to hepatitis $\mathrm{B}$ core antigen levels in the natural history of chronic hepatitis B: a prospective observational study. Medicine. 2014;93:e322.

90. Song L, Liu P, Liu C, Zhang T, Cheng X, Wu H, et al. Quantitative hepatitis B core antibody levels in the natural history of hepatitis B virus infection. Clin Microbiol Infect. 2015;21:197-203.

91. Hou F, Song L, Yuan Q, Fang L, Ge S, Zhang J, et al. Quantitative hepatitis B core antibody level is a new predictor for treatment response in HBeAg-positive chronic hepatitis B patients receiving peginterferon. Theranostics. 2015;5:218-26.

92. Fan R, Sun J, Yuan Q, Xie Q, Bai X, Ning Q, et al. Baseline quantitative hepatitis $\mathrm{B}$ core antibody titre alone strongly predicts HBeAg seroconversion across chronic hepatitis B patients treated with peginterferon or nucleos(t)ide analogues. Gut. 2016;65:313-20.
93. Yuan Q, Song L, Cavalione D, Moriconi F, Cherubini B, Colombatto $\mathrm{P}$, et al. Total hepatitis B core antigen antibody, a quantitative non-invasive marker of hepatitis B virus induced liver disease. PLoS One. 2015; 10:e0130209.

94. Ahmed M, Wang F, Levin A, Le C, Eltayebi Y, Houghton $\mathrm{M}$, et al. Targeting the Achilles heel of the hepatitis B virus: a review of current treatments against covalently closed circular DNA. Drug Disc Today. 2015;20:54861.

95. Liang TJ, Block T, McMahon BJ, Ghany M, Urban S, Guo J, et al. Present and future therapies of hepatitis B: from discovery to cure. Hepatology. 2015;62:1893908.

96. Coffin CS, Lee SS. New paradigms in hepatitis B management: only diamonds are forever. Br Med Bull. 2015;116:79-91.

97. Agarwal K, Fung S, Nguyen T, Cheng W, Sicard E, Ryder $S$, et al. Twenty-eight day safety, antiviral activity, and pharmacokinetics of tenofovir alafenamide for treatment of chronic hepatitis B infection. J Hepatol. 2015;62:533-40.

98. Testoni B, Zoulim F. Liver capsule: validated and potential novel targets to treat hepatitis B virus. Hepatology. 2015;62:1619.

99. Panessa C, Hill WD, Giles E, Yu A, Yu CF, Harvard S, et al. Genotype D amongst injection drug users with acute hepatitis B virus infection in British Columbia. J Viral Hepatitis. 2009;16:64-73. 